\title{
A conversation with a stranger: Debunking religiosity and poverty in South Africa
}

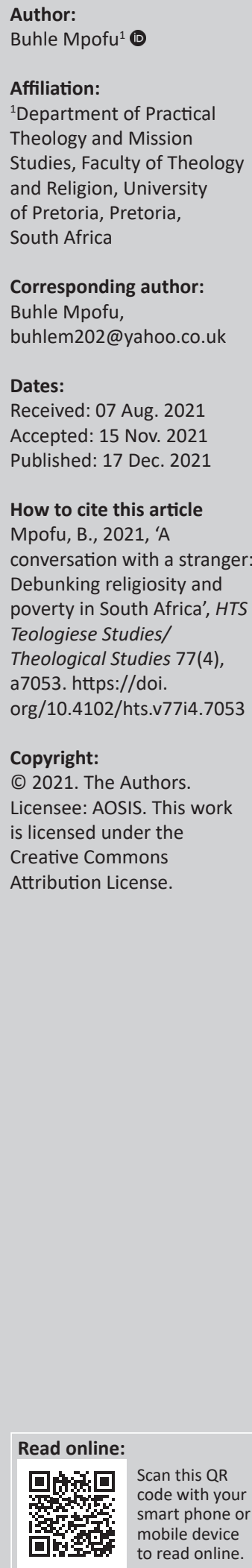

My previous research explored narratives and discourses from marginalised migrants in their quest for survival. This contribution approached the South African context through the lens of the UN Sustainable Development Goal (SDG) 1 'Ending poverty in all its forms' and employed John Hick's notion of 'soul-making' to analyse themes that emerged from a summary of a conversation with a stranger. Faith in God, forgiveness and vulnerability are thematically discussed within the context of the struggle for survival through a conversation held with a homeless man in Sinoville, Pretoria, on 03 August 2021. Inspired by this conversation, the article highlights religious expressions of the homeless, their vulnerability and their perceptions of God to contend that some of the homeless prayerfully deploy religiosity and seek God's guidance to practise Christian values in their daily lives to survive on the margins of society. The contribution challenges dominant narratives on poverty in the context of homelessness and religiosity. The contribution concludes that current developmental discourses need to be decolonised to promote new models for 'development from below' which appreciate the role of religion and promote participation of the marginalised in local development initiatives.

Contribution: This research contributed to the UN SDG 1 on ending poverty in all its forms by interrogating the vulnerability and religious narratives of homeless people in South Africa through the story of an encounter with a homeless stranger.

Keywords: poverty; homelessness; UN SDG 1; liquid modernity; religiosity; development; migrants; South Africa.

\section{Introduction and context}

According the UN Sustainable Development Goal (SDG) 1 (2021): End poverty in all its forms:

More than 700 million people, or 10 per cent of the world population, still live in extreme poverty today, struggling to fulfil the most basic needs like health, education, and access to water and sanitation, to name a few. The majority of people living on less than $\$ 1.90$ a day live in sub-Saharan Africa... [even] For those who work, having a job does not guarantee a decent living. In fact, 8 per cent of employed workers and their families worldwide lived in extreme poverty in 2018. One out of five children live in extreme poverty. Ensuring social protection for all children and other vulnerable groups is critical to reduce poverty. (p. 1)

South Africa remains one of the most unequal societies in the world; and this situation has been described by the University of Cape Town as a 'ticking time bomb' (Davids 2021:1). This has been confirmed by recent unrest, looting and violence which took place in July following the arrest and imprisonment of former president Jacob Zuma after he failed to appear before the 'State Capture Commission' investigating allegations of corruption during his tenure. The 'perfect storm' had been brewing for a long time and when opportunity presented itself, the poor communities turned into anarchy and orchestrated violence that brought Pietermaritzburg and KwaZulu-Natal (KZN) and some parts of Gauteng to a standstill as malls and shops were looted, or torched with very little intervention from security companies or the police. For far too long, extremes of poverty were left unattended and the COVID pandemic exposed and worsened this situation as thousands of people were left homeless when unemployment rose to $34 \%$, and more job losses meant that most families were in lockdown without food. ${ }^{1}$ During the period of unrest, there were also reports of deadly racial tensions in some communities as vigilantism grew in response to crime and looting (Mtshali 2021). The unrest and violence alongside current socio-economic and political tensions created an opportunity for the disgruntled poor communities to loot the shops, in what prompted reflections on the situation of poverty and inequality in South Africa. There were calls for the government to craft a new developmental

1.Government had provided R350 grants to unemployed people for an initial period of months during the lockdown which was extended by an additional six months while the vaccination programmes were rolled out. However, these programmes were delayed and marred with corruption allegations. 
programme that will respond not just to COVID-19, but also address the deepening levels of poverty and engage with the poor and unemployed through a peaceful socioeconomic transformation programme that is rooted in the participation of poor communities; political leaders however, are divided on how this can best be achieved. Economic transformation was at the heart of electoral campaigns for the municipal elections held on the first of November 2021 (Ramaphosa 2021b:1).

The current state of the South African economy is unsustainable and there is a need for a new strategy (SA National Treasury 2021). The current situation demands an urgent attention and there is a need to explore new ways to alleviate extremes of poverty and inequality in South Africa, with a view to ensuring the fulfilment of the UN's SDG's towards poverty alleviation and providing the most basic needs such as health, education, access to water, sanitation, shelter among other needs (UN 2021:1). An effective way in which we can understand the needs of the poor and marginalised is by initiating dialogue with the poor individuals and communities. For example, the Bible is replete with instances where Jesus 'went about healing people' and spent time listening to and providing for the needs of the poor. In Mark 1:29-45; 2:1-12; 5:24-34; and Luke 17:12-19, we learn that Jesus and his disciples walked the dusty roads from village-to-village and city-to-city providing ministry to the poor masses - even staying over at their homes. This is evident in that when they reached Capernaum, Jesus and his disciples spent a night at the home of Peter and his brother Andrew. Therefore, we need to spend more time with the poor in order to understand their needs.

The researcher has previously engaged with people in situations of deprivation through research which explored narratives and ways in which migrants and refugees navigate socio-economic exclusion and negotiate diverse cultural landscapes in South African host communities as part of survival strategies (Mpofu 2019). Among the poor and marginalised, migrants and refugees become victims of unrest in South African communities. It is well documented that foreign migrants are often easy targets of xenophobic violence and their businesses are looted every time there are protests and marches. For example, the Human Rights Watch (HRW) (2020) reported how rioters broke into a shop owned by a Congolese:

$[T]$ he rioters chased him away from his shop, threw stones at him, and forced him to flee. He counted himself lucky to escape unscathed, unlike his experience in a similar situation in 2008 when rioters beat him, and he sustained serious injuries. Reflecting on his experience, Jean told Human Rights Watch, (HRW) 'I am not feeling happy even though I am alive. I am trying not to be so angry, but I am so angry'. (p. 1)

The socio-economic impact of COVID-19 has been devastating; there were many job losses as some sectors of the industry such as tourism and restaurants remained closed, poverty levels increased, crime and violence escalated, and political instability which had been brewing from the divisions within the ruling African National Congress (ANC), worsened further with the imprisonment of former president Jacob Zuma whose supports felt that he was being targeted for political reasons. One of the political analysts Aubrey had warned that there are 'four storms which will converge into one: poverty, eNkandla, the Royal divisions, and frustrations over the poor handling of COVID-19 by the government' (Aubry 2021).

During the initial COVID-19 lockdown period in March 2020, most homeless people were provided temporal shelter as part of the government's response to the pandemic. However, implementation of mechanisms to provide shelter and safety to migrants and refugees has not been effective as some foreign-owned shops were looted during the protests and this threatened to harm food security and exports. ${ }^{2}$ Addressing the nation on the evening of 16 July 2021, President Cyril Ramaphosa (2021b) shared his anguish over these devastating events that had swept the provinces of KZN and Gauteng within a space of four days, and he made the following observations:

Earlier today, I visited the areas of KwaMashu, Springfield, Mobeni and Umlazi in KwaZulu-Natal, which have been sites of unprecedented violence and destruction over the past several days. The streets and buildings I saw bear the scars of looting and mayhem... The current instability and ongoing incitement to violence constitutes a direct contravention of the Constitution and the rule of law. These actions are intended to cripple the economy, cause social instability and severely weaken - or even dislodge - the democratic state... They have sought to exploit the social and economic conditions under which many South Africans live... (p. 2)

As a contribution to the UN SDG 1 on alleviation of poverty, this research interrogated vulnerability and religiosity of homeless people in South Africa. It was inspired by a conversation held with a homeless man, and the research analysed the summary of points from this conversation to engage the concept of development from a religious perspective. It employed Hick's notion of 'soul making' to discuss the themes of relationship with God, forgiving, vulnerability and religion within the context of developing the development nexus. This reflection was undertaken in order to understand how the poor and marginalised survive the harsh reality of poverty. In particular, the researcher was interested to interrogate homelessness in order to determine whether there are any inferences that can be drawn with the survival strategies uncovered in previous research on liminality, vulnerability, and migrant experiences or discourses. Although this informant was not a foreign migrant, it is significant to highlight that his survival strategies deployed mobility as he moved from Soshanguve and relocated to a makeshift home in Sinoville, closer to the dumping sites where most homeless people collect recycling material for economic survival.

2.For more details see Kruger (2021). This article laments the risk of food security and exports because of these developments which emants the risk of food security and exports because of these developments which emanated from KZN, a province that
contributes $16 \%$ to GDP, largely through agriculture and has one of the biggest ports in Durban which ground to halt because of economic disruptions. 


\section{A conversation with a homeless man}

I met the homeless man on Tuesday, 3rd August, while walking up the street in the local community. The man struggled to walk as he carried four heavy plastic bags. The bags seemed so heavy that he had to carry them two at a time and kept moving back-and-forth in a manner akin to somebody who is not normal. He looked dirty, and you would understand why a few people came closer to him, especially in this suburban neighbourhood. Having met vagrants and homeless people in the past, it was not anything new to see someone moving around with their possessions and sometimes begging for food and old clothes as they search for temporal places to sleep overnight. Sometimes it is at the park or old buildings. They are a common sight in most South African cities - often on the outskirts or margins of society. They are often labelled amapara (parasites). This label condemns them as outcasts in most communities where they are neither trusted nor treated with dignity. Most South African communities consider homeless people to be drug addicts who survive on committing crime to find money to sustain their addiction. As a result, most of them are rejected by their communities. It is important to highlight this situation so that we can appreciate the need to debunk this narrative. I, therefore, gathered courage and started a conversation with him.

\section{Summary points from the conversation}

The man was carrying a heavy load of material which he had collected from the neighbourhood in Sinoville. It turned out that he survives on collecting clothes and other valuables and he later sends them to his family where some of them are sold. On this day, he got a bag with shoes and hid it so that he can keep searching for more material. On his return, the bag had been stolen and he suspected one of his homeless friends who stays in the vicinity, but the friend denied any involvement. After the argument, he decided to forgive him and went on searching for other items. It was during his second trip of the day that he came back with loads of new items including a cell phone which he valued at R5000.

The main points that he highlighted in sharing his story were as follows:

1. We must always be faithful and seek God's guidance in everything we do.

2. If we forgive those who trespass against us, God will also forgive us.

3. Forgiving other people opens new doors for opportunities, even in our vulnerability.

\section{Literature review Defining vulnerability}

There have been significant discussions regarding the concept of vulnerability in academia, especially from a bioethics perspective (Cunha \& Garrafa 2016; Luna 2009). A Scopus review using the search terms 'police' and 'vulnerable' or 'vulnerability' showed that social science academic journal articles on these terms had risen from 5 in 2001 to 52 in 2016. At one level academics argue vulnerability can be viewed as a universal concept, inherent in all people, and core to the very nature of what it means to be human (Fineman 2010). However, the subject eludes a precise or agreed definition, which means there is no consistency in its meaning or use. Some argue that a single definition is not appropriate (Wrigley \& Dawson 2016), with Fineman (2010:269) postulating that 'variations amongst humans mean we have particular experiences of vulnerability', therefore a simple definition would deny its complexity. Similarly, Wrigley (2015) stated defining vulnerability offers little to academia, as it does not explain the word. Some resist a formal definition on wider, structural grounds. Green (2007) argued that:

... even if vulnerability could be ordered and measured, such research would probably still fall into the positivist trap of ignoring the social processes that both label people as victims and define their appropriate responses to harm caused. (p. 94)

Others resist and avoid using the term 'vulnerability' because of the connotations it constructs regarding the inherent weakness of specific groups (Chakraborti \& Garland 2012), with such labelling generating stigma and negative effects (Noakes \& Wincup 2004). Furthermore, some scholars have considered how some citizens are made vulnerable by the state, challenging the labels used on people learning to overcome or live with their vulnerability - such as drug users who have overcome addiction. As 'vulnerability' is such a strong emerging theme, and although inherent difficulties exist in composing a definition for it, the absence of a definition generates three specific problems for police forces and practitioners of state security functions. First, UK police force is now measured on their approach to tackle vulnerability. As such, there should be common agreement on what an appropriate standard should be. Second, police forces require some consistency of approach if they are to establish expertise and good practice. Finally, if the concept remains fluid there is a danger that the police will suffer mission creep, overlapping into services that may be more appropriately delivered by another institution. These issues demand the need for further definitional and operational clarity. The Oxford English dictionary describes the term vulnerability as the 'exposure to being harmed or attacked'. Harmon (2015:1) provided a similarly straightforward explanation, highlighting that it involves those individuals, '... easily harmed physically, mentally or emotionally. Vulnerable people are at a higher risk of being harmed'. Similarly, Cops and Pleysier (2011:59) referred to vulnerability as 'the perception of exposure to danger, a loss of control over the situation and a perceived inadequate capacity to resist the direct and indirect consequences of victimisation'. Green (2007:92) stated that vulnerability 'is often used to express the level of risk posed to certain groups or individual'.

\section{Discussion on the conversation}

In this section, I will discuss the themes of relationship with God, forgiveness and vulnerability before highlighting the 
significance of the interface between religion and development in order to underscore the significance of the conversation held with a homeless man.

\section{Relationship with God}

Given that in the South African context the Church played a major role in the struggle for liberation, religion needs not only be appropriated an instrumental agenda, but it should be acknowledged as one of the key factors in socio-economic transformation processes. This is critical because of the nature of religious conceptualisations which inform public discourse on development and occupies an important societal role through religious structures which enhance selfdetermination. Despite some precautions which should be taken to guard against religious fundamentalism which often disrupts creative engagement between religious communities and developmental agencies, the productive role of religion and faith communities as agents for socio-economic transformation needs to be acknowledged. Such recognition affirms the participation of poor communities as part of critical discourses which are contextual and approach 'development from below'.

Considering that the UN SDG 1 aims to end poverty in all its forms, I was inspired by this story for a number of reasons. Firstly, the homeless man I had judged to be abnormal had respect for me and spoke of his faith in God in a manner that I did not expect. Despite his suffering and loss of possessions, he had a relationship of faith with God and led a prayerful life which opened more opportunities for him to experience God's providence. This demonstrates that homeless people rely on religion to execute their agency in addressing to their plight of unemployment, hunger and homelessness, that are a result of successive corrupt regimes which have failed to draw on indigenous knowledge systems and religious capital to empower the poor.

A broader understanding of how the poor prayerfully seek to build relationships with God in their struggle for survival will facilitate the decolonisation of the developmental agenda and locate government policies within the context of the experiences of the poor and marginalised. Such an approach will generate an 'invisible Aid economy' (Clarke \& Tittensor 2014:1) where the masses play an active role where they collectively address unrest and ensure political instability in the realisation that peace and stability are essential for economic development and the well-being of society. Economic justice requires that people do not feel excluded in the economic activities; otherwise they will find it easy to collapse the system because it does not benefit them.

Another profound observation demonstrating a good relationship with God was the faith and gratitude of this homeless brother. Despite his challenging situation, he profoundly exhibited a 'gratitude attitude' through which he expressed his unwavering faith in God. According to Manala (2018:1), gratitude is important as a Christian virtue and as a socioreligious phenomenon, and for human happiness and well-being. Such an expression of gratitude is more profound when exhibited by a homeless person who lives one day at a time. Such gratitude was highlighted in the conversation with the stranger who smiled and laughed as he shared his painful encounter. He seemed to have nourished a relationship of faith and trust in God that 'supplanted the attitude of failure' and replaced his sorrows with joy.

\section{Forgiving}

Secondly, the homeless man was able to forgive. To forgive is not easy, especially when one is faced with pain and suffering. South Africa is a society still dealing with the painful past which resulted from the oppressive apartheid system that marginalised black majority. Whether it is about Helen Zille's tweets such as 'black privilege... is being able to loot a country and steal hundreds of billions and get re-elected' or it is about the recent Democratic Alliance (DA) election campaign poster in Phoenix which said 'ANC calls you racists, DA calls you heroes', South African politics reflects bitter racial divisions which are a far cry from the ideal of 'non-racialism' which was envisaged in 1994 at the dawn of democracy. There is a need to revisit the reconciliation as a way to encourage forgiving one another. It is easy to justify anger and bitterness with conditions of deprivation, as some often do. According to De Vries (2013):

Forgiving means accepting the fallibility of the human condition. It demonstrates courage, vulnerability, integrity and trust, all constructive ways to build collaboration and connections. Forgiveness fosters healing, restitution, and restoration in both the giver and the receiver. It facilitates excellence and improvement. But what it does not mean is not forgetting forgiveness does not mean condoning whatever hurt may have been caused. On the contrary, remembrance is important because without it, there is always a likelihood that past hurts will be repeated. Forgiving thus means taking the sting out of a memory that otherwise threatens to poison our existence. (pp. 3-4)

The homeless was a man in streets - homeless but not hopeless. He was rejected by society but received by God. He may have not attended elite schools in suburbs, but it seemed that he had the wisdom from above. The stranger embraced forgiving not because he could afford its costs, but because he understood and clearly articulated the idea that we are all God's children even if we do not love each other and steal from each other. He decided to forgive so that God can also forgive him. Here was a man who had accepted the 'fallibility of the human condition' with courage that transcends his vulnerability. The homeless man may not have attended any counselling sessions offered in the high echelons of society, but he sought 'healing, restitution, and restoration' to improve his circumstances. Although he could vividly remember his pain, he did not allow his existence to be poisoned by the pain and loss he endured.

In a seemingly hopeless situation, his faith in God opened a way for him to forgive and that seemingly invited God's intervention in his situation. This resonates with what McCann and Johnson (2017) observed when they cited Hick (1966) in his classic work Evil and the God of Love: 
In the wake of repentance there should occur a gradual transformation of the individual, in which the damage wrought by $\sin$ is repaired, and the character traits appropriate for friendship with God are nourished. Remorse, anger and bitterness have to be replaced by gratitude, peace and hope; attitudes of failure must be supplanted by a sense of worth; rationalization has to give way to self-understanding. Above all, the believer has to develop such virtues as humility, patience, courage, and concern for others - to give up selfishness in favor of charity. Hick calls this process 'soul-making'. (Hick 1966:289297 in McCann \& Johnson 2017)

When the homeless man cried to God, he invoked the idea of 'repairing damage wrought by $\sin ^{\prime}$ as he sought God. In forgiveness, he experienced peace with God as he did away with 'anger and bitterness', replacing them with 'gratitude, peace and hope'. The stranger invoked what Hick (1966) called 'soul-making' process as he transformed his attitude in a manner rarely imagined for the homeless people in the streets. It was after this transformative 'soul-making' introspection that he drew God's attention

\section{Vulnerability}

Another theme which emerged from this conversation is vulnerability. According to Keay and Keaby (2018:2), vulnerability has been an elusive term to define. They cited Fineman (2010:269) who postulated that 'variations amongst humans mean that we have particular experiences of vulnerability' and the Oxford Dictionary which describes vulnerability as 'exposure to being harmed or attacked'. For Harmon (2016:1), vulnerability involves the circumstances of those individuals in society '...easily harmed physically, mentally or emotionally'. Therefore, the situation of homelessness places individuals without shelter at the risk of being harmed 'physically, mentally or emotionally'. This theme highlights the risks associated with vulnerability within the context of homelessness. This conversation reflects that homeless people steal from each other, fear for the safety of their possessions, and even fear for the safety of their lives. This stranger highlighted these excruciating and life-threatening conditions in our conversation.

Poor and homeless people face a myriad of challenges as they all seek to survive the harsh realities of life in the streets. According to McCann and Johnson (2017), Hick's notion of 'soul making', having to undergo 'gradual transformation of the individual, in which the damage wrought by $\sin$ is repaired, and the character traits appropriate for friendship with God are nourished', becomes tainted as 'remorse, anger and bitterness', constantly affect them. Some are angry with their families, angry with the government and bitter that they have no food or a safe place to call home. Practicing forgiving, expressing gratitude and maintaining faith in God becomes a challenging religious task under these life-threatening circumstances.

Supplanting 'attitudes of failure' with a sense of worth is a daunting task for some, but this homeless man had done it with ease. His example demonstrates that some homeless people can overcome their circumstances and reclaim selfworth. Although it is expected that ' $[I] \mathrm{n}$ the wake of [believing in God] there should occur a gradual transformation of the individual, in which the damage wrought by sin is repaired' (McCann \& Johnson 2017:3). There is a need for inclusive social and economic transformation in South Africa. This is necessary given the rapidly changing context after the impact of COVID-19 and unrest which resulted in looting and destruction of infrastructure. The poor have been stripped of their dignity as a result of COVID-19 and its devastating impact and effects on the global economy, and the religious and social activities.

South Africa is undergoing transformation as it is still geographically organised along racial, ethnical and tribal lines. Although there is a generally accepted view that people are now free to live where they desire, the socio-economic organisation is largely characterised by implicit racial discrimination and marginalisation of the poor through consumerist strategies which separate individuals on the basis of privilege and wealth. This is partly as a result of the global economic architecture which thrives on practices of eliminating differences between individual and communities. Essentially, this means that the poor risk being arrested and detained if they cross the boundaries of spatial separation:

$[W]$ hich is reproduced in the supermarket: the privileged places of consumption... the 'emic' ones, consisting in 'vomiting and spitting the others out, considering them as being incurably strangers and aliens, in prohibiting physical contact, dialogue, social relationships and any kind of commercium, commensality or connubium. The extreme variants of this emic strategy are, today as always, imprisonment, deportation and physical suppression. Two updated forms, refined (modernized) are the spatial separation, urban ghettos, the selective access to spaces. The second strategy consists of a so-called "disalienation" [sic] of stranger ...' (Bauman 2000:112)

This description of the current global conditions resonates with the situation of homelessness; the 'incurable strangers and aliens...' prohibited and isolated in 'physical contact, dialogue, [and] social relationships'. The uncertainty characterising the South African context presents an opportunity for something new to emerge - a society and economic architecture that restores the dignity of the poor and homeless.

\section{Religion and development}

There is a need for more research in exploring the transformative nature of religiosity in developmental discourses, especially from the perspectives of the poor and homeless. The role of religion in development has recently been acknowledged by scholars and development practitioners. For example, see Clarke (ed. 2013), Handbook of Research on Development and Religion; Deneulin and Rakodi (2011), Revisiting Religion: Development Studies Thirty Years On; Bompani (2015), Religion and Development in Sub-Saharan Africa: An Overview; Bompani (2019), Religion and Development: Tracing the Trajectories of an Evolving Sub- 
Discipline; Jones and Petersen (2011), Instrumental, Narrow, Normative? Reviewing Recent Work on Religion and Development; Mahajan and Jodhka (eds. 2010), Religion, Community and Development: Changing Contours of Politics and Policy in India; and Köhrsen and Heuser (eds. 2020), Faith-based Organizations in Development Discourses and Practice. Some scholars have also explored the contribution of the other traditions and religions such as Islam in developmental agenda. These are exemplified in the works of Deneulin and Bano (2009), Religion in Development: Rewriting the Secular Script; Ozsoy (2011), Islamic Banking: Background, Theory and Practice; Ridell (2013), Islam as Aid and Development; Clarke and Tittensor (2014), Islam and Development: Exploring the Invisible Aid Economy; Fountain, Robin and Feener (eds. 2015), Religion and the Politics of Development: Critical Perspectives on Asia.

In highlighting the intersections between religion and development, it is important to emphasise that most African scholars have been critical of Western notions of development. For example, Ziai (2016) employed:

$[T]$ he archaeological and genealogical methods of Michel Foucault to trace the origins of development discourse back to late colonialism and notes the significant discontinuities that led to the establishment of a new discourse and its accompanying industry. (p. 1)

Therefore, in other studies, there is a need to uncover more authoritarian elements in development discourse and ensuring that the oppressive elements are unmasked so that we depoliticise development while appreciating and embracing its progressive appropriations.

Religion and theological engagement can make significant contribution in the reimaging of a new economic programme which will ensure participation of the poor South African masses and promote peace and stability. Such an approach will not only alleviate poverty, but will also avert catastrophic scapegoating where foreign migrants become victims of xenophobic attacks. As the developments around COVID-19 disruptions unfold and with churches having to adjust to the new 'normal', there is another unnoticed phenomenon taking place - religious practices and individual spirituality have evolved - this also includes that of the homeless people. New forms of spirituality have emerged as people grapple with new challenges.

\section{Conclusion}

This contribution engaged the UN SDG 1 'on ending poverty in all its forms' and employed Hick's notion of 'soul-making' to analyse themes of faith in God, forgiveness and vulnerability within the context of development through a conversation held with a homeless man in Sinoville, Pretoria, on 03 August 2021 to highlight the need for continuous reflections on the narratives of the poor and marginalised insofar as they navigate dominant ideological conditions that breed inequality. Given that this conversation demonstrates the significance of faith and forgiveness, the Church has a responsibility to facilitate social justice programmes aimed at alleviating poverty and addressing the inequalities that are prevalent in South African society.

One of the profound observations from this conversation was that the poor and homeless are often perceived as 'ungodly', 'parasites' who are drug addicts and survive on criminal activities. This contribution challenged these societal perceptions of the homeless by demonstrating how some of the homeless people prayerfully seek God's guidance and gratefully forgive those who sin against them, as they engage in 'soul making' processes aimed at reclaiming their worth and human dignity on the margins of society. Under the conditions of deprivation, they may look dirty, but some are religiously smart and work hard to earn an honest life. Therefore, our perceptions of homelessness and religiosity need to be debunked, challenged and transformed.

\section{Acknowledgements}

I am indebted to the homeless stranger who inspired this contribution through a conversation we had on 03 August 2021 in Sinnoville, Pretoria.

\section{Competing interests}

The author declares that he has no financial or personal relationships that may have inappropriately influenced him in writing this article.

\section{Author's contributions}

B.M. is the sole author of this research article.

\section{Ethical considerations}

The data analysed in this contribution emerged from a conversation with a homeless stranger. At the time of the conversation, there was no intention to record the interview and as a result, permission was not sought. No names were used in the study and this guarantees confidentiality and protection of the participant.

\section{Funding information}

The research received no specific grant from any funding agency in the public, commercial, or not-for-profit sectors.

\section{Data availability}

Data sharing is not applicable to this article as no new data were created or analysed in this study.

\section{Disclaimer}

The views and opinions expressed in this article are those of the author and do not necessarily reflect the official policy or position of any affiliated agency of the author. 


\section{References}

Aubry, M., 2021, E News Channel Africa (ENCA) News Interview, 04 July 2021, n.p. Bauman, Z., 2000, Liquid modernity, Polity Press, Cambridge.

Bompani, B., 2015, 'Religion and development in sub-Saharan Africa: An overview', in E. Tomalin (ed.), The Routledge handbook of religions and global development, pp. 101-113, Routledge, New York, NY.

Bompani, B., 2019, 'Religion and development: Tracing the trajectories of an evolving sub-discipline', Progress in Development Studies 19(3), 171-185. https://doi. org/10.1177/1464993419829598

Chakraborti, N. \& Garland, J., 2012, 'Reconceptualizing hate crime victimization through the lens of vulnerability and "difference", Theoretical Criminology 16(4), 499-514.

Clarke, M. (ed.), 2013, Handbook of research on development and religion, Elgar, Cheltenham.

Clarke, M. \& Tittensor, D. (eds.), 2014, Islam and development: Exploring the invisible aid economy, Ashgate, Farnham.

Cops, D. \& Pleysier, S., 2011, "'Doing gender"' in fear of crime: The impact of gender identity on reported levels of fear of crime in adolescents and young adults', British Journal of Criminology 51(1), 58-74.

Cunha, T. \& Garrafa, V., 2016, 'Vulnerability', Cambridge Quarterly of Healthcare Ethics 25, 197-208. https://doi.org/10.1017/S096318011500050X

Davids, N., 2021, Inequality in South Africa is a 'ticking timebomb', viewed 15 October 2021, from https://www.news.uct.ac.za/article/-2021-05-21-inequality-in-south africa-is-a-ticking-timebomb.

Deneulin, S. \& Bano, M., 2009, Religion in development: Rewriting the secular script, Zed Books, London.

Deneulin, S. \& Rakodi, C., 2011, 'Revisiting religion: Development studies thirty years on', World Development 39(1), 45-54. https://doi.org/10.1016/j.worlddev.2010.05.007

De Vries, F.R., 2013, The art of forgiveness: Differentiating transformational leaders, Faculty and Research Working Paper, viewed 07 August 2021, from https://sites. insead.edu/facultyresearch/research/doc.cfm?did $=52275$.

Fineman, M., 2010, 'Vulnerable subject and responsive state', Emory Law Journal 60(2), 251-275.

Fountain, P., Robin, B. \& Feener, M. (eds.), 2015, Religion and the politics of development: Critical perspectives on Asia, Palgrave Macmillan, Hampshire.

Green, S., 2007, 'Crime, victimisation and vulnerability', in S. Walklate (ed.), Handbook of victims and victimology, Willan, Cullompton.

Harmon, A., 2015, Vulnerable populations, Salem Press Encyclopaedia, CA.

Hick, J., 1966, Evil and the God of love, Harper \& Row, New York, NY.

Human Rights Watch, 2020, They have robbed me of my life. Xenophobic violence against non-nationals in South Africa, viewed 21 July 2021, from https://www. hrw.org/report/2020/09/17/they-have-robbed-me-my-life/xenophobic-violenceagainst-non-nationals-south.

Jones, B. \& Petersen, M.J., 2011, 'Instrumental, narrow, normative? Reviewing recent work on religion and development', Third World Quarterly 32(7), 1291-1306. https://doi.org/10.1080/01436597.2011.596747
Keay, S.K. \& Kirby, S., 2018, 'Defining vulnerability: From the conceptual to the operational', Policing 12(4), 428-438. https://doi.org/10.1093/police/ pax046

Köhrsen, J. \& Heuser, A. (eds.), 2020, Faith-based organizations in development discourses and practice, Routledge, Abingdon.

Kruger, A., 2021, KwaZulu-Natal cannot afford this, nor can the rest of SA, viewed 17 July 2021, from https://www.moneyweb.co.za/news/economy/kwazulu-natalcannot-afford-this-nor-can-the-rest-of-sa/.

Luna, F., 2009, 'Elucidating the concept of vulnerability: Layers not labels', Internationa Journal of Feminist Approaches to Bioethics 2(1), 121-139.

Mahajan, G. \& Jodhka, S.S. (eds.), 2010, Religion, community and development: Changing contours of politics and policy in India, Routledge, New Delhi.

Manala, M.J., 2018, 'Gratitude as a Christian lifestyle: An Afro-reformed theological perspective', HTS Teologiese Studies/Theological Studies 74(4), a5117. https://doi. org/10.4102/hts.v74i4.5117

McCann, H.J. \& Johnson, D.M., 2017, 'Divine providence', in E.N. Zalta (ed.), The Stanford Encyclopedia of philosophy, viewed 06 August 2021, from https://plato. stanford.edu/archives/spr2017/entries/providence-divine/.

Mpofu, B., 2019, 'Migration, xenophobia and resistance to xenophobia and socio-economic exclusion in the aftermath of South African Rainbowism', Alternation 26(1), 153-173. https://doi.org/10.29086/2519-5476/2019/ v26n1a7

Mtshali, S, 2021, 20 confirmed dead in Phoenix as racial tensions simmer, viewed 21 July 2021, from https://www.iol.co.za/news/politics/20-confirmed-deadin-phoenix-as-racial-tensions-simmer-b0d56407-5cb6-46ef-af82in-phoenix-as

Noakes, L. \& Wincup, E., 2004, Criminological research, Sage, London.

Ozsoy, I., 2011, 'Islamic banking: Background, theory and practice', in G. ter Haar (ed.), Religion and development: Ways of transforming the world, pp. 159-182, Columbia University Press, New York, NY.

Ramaphosa, C.M., 2021, President Cyril Ramaphosa declares Election Day 1 November 2021 as public holiday, viewed 15 October 2021, from https://www.gov.za/ speeches/president-cyril-ramaphosa-declares-election-day-1-november-2021public-holiday-12-oct-2021.

SA National Treasury, 2021, Economic transformation, inclusive growth, and competitiveness: Towards an economic strategy for South Africa, Prepared by Economic Policy, National Treasury, viewed 15 October 2021, from http://www. treary. Pov.za/comm media/press/2019/Towards\%20an\%20Economic\% treasury.gov.za/comm_me mofor\%20SA.pdf.

United Nations (UN), 2021, United Nations Sustainable Development (SDG) Goal 1 End poverty in all its forms everywhere, viewed 15 October 2021, from https:// www.un.org/sustainabledevelopment/poverty/.

Wrigley, A., 2015, 'An eliminativist approach to vulnerability', Bioethics 29(7), 478-487.

Wrigley, A. \& Dawson, A., 2016, 'Vulnerability and marginalized populations', in D. Barrett, L.W. Ortmann, A. Dawson, C. Saenz, A. Reis \& G. Bolan (eds.), Public health ethics: Cases spanning the globe, Springer.

Ziai, A., 2016, Development discourse and global history: From colonialism to the sustainable development goals, Routledge, London. 